\title{
1 The diversity and functional capacity of microbes associated with coastal phototrophs
}

3 Khashiff Miranda ${ }^{1,2^{*}}$, Brooke L. Weigel ${ }^{3,4}$, Emily C. Fogarty ${ }^{5,6}$, Iva A. Veseli ${ }^{7}$, Anne E. Giblin ${ }^{8}$, 4 A. Murat Eren ${ }^{5,9}$, Catherine A. Pfister ${ }^{3,10}$

$6 \quad{ }^{*}$ Corresponding author email: khashiff.miranda.1@ulaval.ca

$7{ }^{1}$ The College, The University of Chicago, Chicago, IL, 60637, USA

$8 \quad 2$ Département de biologie, Université Laval, Québec, QC, G1V 0A6, Canada

$9{ }^{3}$ Committee on Evolutionary Biology, The University of Chicago, Chicago, IL, 60637, USA

$10{ }^{4}$ Friday Harbor Laboratories, University of Washington, Friday Harbor, WA 98250, USA

$11{ }^{5}$ Department of Medicine, The University of Chicago, Chicago, IL 60637, USA

$12{ }^{6}$ Committee on Microbiology, The University of Chicago, Chicago, IL 60637, USA

$13{ }^{7}$ Biophysical Sciences Program, The University of Chicago, Chicago, IL, 60637, USA

$14{ }^{8}$ The Ecosystems Center, The Marine Biological Laboratory, Woods Hole, MA, 02543, USA

$15{ }^{9}$ Josephine Bay Paul Center, Marine Biological Laboratory, Woods Hole, MA 02543, USA

$16{ }^{10}$ Department of Ecology \& Evolution, The University of Chicago, Chicago, IL, 60637 USA

\section{Abstract}

19 Coastal marine phototrophs exhibit some of the highest rates of primary productivity in the

20 world. They have been found to host a diverse set of microbes, many of which may impact the

21 biology of their phototroph hosts through metabolisms that are unique to microbial taxa. Here we

22 characterized the metabolic functions of phototroph-associated microbial communities using

23 metagenomes collected from 2 species of kelp (Laminaria setchellii and Nereocystis luetkeana) 
24 and 3 marine angiosperms (Phyllospadix scouleri, P. serrulatus and Zostera marina), including

25 the rhizomes of two surfgrass species (Phyllospadix spp.) and the seagrass Zostera marina, and

26 the sediments surrounding $P$. scouleri and Z. marina. Using metagenomic sequencing, we

27 describe 72 metagenome assembled genomes (MAGs) that potentially benefit from being

28 associated with macrophytes and may contribute to macrophyte fitness through their metabolic

29 gene content. All host-associated metagenomes contained genes for the use of dissolved organic

30 matter from hosts and vitamin $\left(\mathrm{B}_{1}, \mathrm{~B}_{2}, \mathrm{~B}_{7}, \mathrm{~B}_{12}\right)$ biosynthesis. Additionally, we found a range of

31 nitrogen metabolism genes that transform dissolved inorganic nitrogen into forms that may be

32 more available to the host. The rhizosphere of surfgrass and seagrass contained genes for

33 anaerobic microbial metabolisms, including nifH genes associated with nitrogen fixation, despite

34 residing in a well-mixed and oxygenated environment. The range of oxygen environments

35 engineered by macrophytes likely explains the diversity of both oxidizing and reducing microbial

36 metabolisms, and contributes to the functional capabilities of microbes and their influence on

37 carbon and nitrogen cycling in nearshore ecosystems.

\section{Importance}

40 Kelps, seagrasses and surfgrasses are ecosystem engineers on rocky shorelines where they show

41 remarkably high levels of primary production. Through analysis of their associated microbial

42 communities, we found a variety of microbial metabolisms that may benefit the host, including

43 nitrogen metabolisms and the production of B vitamins. In turn, these microbes have the genetic

44 capability to assimilate the dissolved organic compounds released by their phototroph hosts. We

45 describe a range of oxygen environments associated with surfgrass, including low-oxygen

46 microhabitats in their rhizomes that host genes for nitrogen fixation. The tremendous 
47 productivity of coastal phototrophs is likely due in part to the activities of associated microbes and an increased understanding of these associations is needed.

\section{Introduction}

51 We are experiencing a paradigm shift in biology with the recognition that many species exist as a

52 consortium with microbes (1). These microbial associations are nearly ubiquitous, spanning a

53 diversity of hosts across ecosystems. In coastal marine environments, phototrophic microbial

54 hosts are diverse and range from marine angiosperms to large eukaryotic protists (macroalgae).

55 Different macroalgal host species $(2,3)$ and different phototroph tissues $(4,5)$ host distinct

56 microbial communities numbering in the millions per $\mathrm{cm}^{2}$ of host tissue (6), yet we still know

57 little about the functional role the microbiome plays in host fitness or how the host influences the

58 microbiome. The microbiome of phototroph species has been shown to have metabolisms that

59 provide nitrogen to the host $(7,8)$. Bacteria also supply B vitamins (9) and affect development of

60 their host (10). Further, the contributions that marine phototrophs make to host carbon and

61 nitrogen cycling have largely ignored the role that microbes play. Even as we begin to describe

62 their microbiome, we are discovering that environmental change affects these communities (11).

63 For many of the foundational phototrophic species in the coastal ocean, our understanding of the

64 diversity and role of their microbiome is nascent.

66 A unique aspect of host-associated microbes are the strong gradients in oxygen that they

67 experience due to the biological activities of the host. The photosynthetic and respiratory

68 activities of the host can generate a 'phycosphere' (12) where the host influences the physical

69 environment experienced by microbes, sometimes over micron or mm scales. For example, the 
70 basal leaf meristem of the seagrass Zostera ranges from oxic to anoxic conditions over a scale of

71300 microns when measured with oxygen microsensors (13). This range of oxygen

72 concentrations likely selects for a diversity of microbial metabolisms in association with

73 macrophytes.

75 Another factor important to the microbial metabolisms associated with coastal macrophytes is

76

77

nutrient availability. In coastal systems, nitrogen can limit primary production and microbial associates that aid in accessing nitrogen might be selected. Microbial metabolisms that can increase the available dissolved inorganic nitrogen (DIN) for the host (14) include pathways that cleave carbon-nitrogen bonds to generate ammonium. This ammonification in biological systems can result from a diversity of hydrolases, including ureases and other enzymes that cleave C-N bonds (15). Further, microbes that fix atmospheric nitrogen have been discovered in an increasing number of taxa $(8,16)$, now recognized to include heterotrophic as well as phototrophic taxa (17-19). Nitrogen fixation was previously assumed to be restricted to nitrogenpoor environments, but has been quantified recently in systems thought to be nitrogen-rich (8, 20), an enigmatic finding given that nitrogen fixation is a costly metabolic process that consumes 16 ATPs per $\mathrm{N}_{2}$ fixed (21). Sediments where oxygen is low and nutrients can be depleted by macrophytes, such as the rhizosphere of seagrasses have provided evidence of nitrogen fixation (22-26). The recent discovery that nitrogen fixation takes place on particles in the coastal ocean where nitrate is relatively abundant $(8,20)$ suggests that nifH genes could be abundant in other nearshore systems. 
92 Microbial metabolisms that synthesize compounds and vitamins needed by seaweeds and

93 seagrasses may also underlie host-microbe exchanges. The active form of Vitamin B1 (thiamin)

94 is essential for all organisms and is involved in carbohydrate and amino acid metabolisms.

95 Vitamin B2 (riboflavin)-binding proteins are co-enzymes in various oxidases and are involved in

96 photosynthesis and phototropism (27). Vitamin B7 (biotin) is a cofactor for acetyl coenzyme A

97 (coA) which is essential for fatty acid synthesis. Vitamin B12 (cobalamin) is required as a

98 coenzyme in the mitochondria for many algae, yet they depend upon prokaryotes to produce it

$99(9,28)$. Thus, marine macrophytes may be auxotrophic for key vitamins, and their production by

100 host-associated bacteria may be another basis for phototroph-microbiome interactions in nature.

102 Hosts might reciprocally benefit microbes, especially if heterotrophic microbes benefit from the

103 dissolved organic carbon that is released by their hosts. Of the carbon that is fixed, kelp have

104 been demonstrated to release $15-16 \%$ of it as dissolved organic matter $(29,30)$, and seagrasses

105 too provide a constant source of dissolved organic carbon $(31,32)$, likely stimulating

106 heterotrophic bacterial processes (33). These rates of organic carbon release, often involving

107 highly labile organic carbon compounds (34), could provide the basis for reciprocal benefits

108 between microbes and their associated hosts.

110 Here, we analyzed microbial metagenomes collected from 5 different coastal phototrophs to

111 determine if there is functional genomic evidence of microbial metabolisms that could

112 reciprocally benefit host and microbes. We analyzed the surface microbiome on the blade of two

113 kelp species (Laminaria setchellii and Nereocystis luetkeana) and the surfgrass Phyllospadix

114 scouleri, the rhizomes of P. scouleri, P. serrulatus, and the seagrass species, Zostera marina, and 
115 the sediment surrounding the rhizomes of P. scouleri and Z. marina. We quantified the variable

116 oxygen environment in the rhizomes of Phyllospadix spp. to determine if they allow for aerobic

117 as well as anaerobic metabolisms. We analyzed the microbial taxa present and examined their

118 gene content to estimate their functional and metabolic capacities. We hypothesized that

119 microbial partners: 1) enhance host access to dissolved inorganic nitrogen through nitrogen

120 recycling, ammonification and nitrogen fixation, 2) provision vitamins $\mathrm{B}_{1}, \mathrm{~B}_{2}, \mathrm{~B}_{7}, \mathrm{~B}_{12}$, and 3 ) use

121 a diversity of abundant dissolved organic carbon exudates from the host. We tested whether

122 microbial taxonomy and function differed across hosts and host tissue types, and whether

123 anaerobic metabolisms were present in low- $\mathrm{O}_{2}$ environments (e.g., rhizomes and sediment).

124 Through this study, we find that the range of oxygen environments engineered by host

125 phototrophs likely explains the diversity of both oxidizing and reducing microbial metabolisms,

126 and contributes to the functional capabilities of microbes and their influence on carbon and

127 nitrogen cycling in nearshore ecosystems.

\section{Methods}

130 Sampling and DNA Extraction

131 We collected metagenome samples from the surfaces of 5 different phototroph species (Table

132 S1). The surface of Phyllospadix scouleri blades, Laminaria setchellii fronds and the inner bulbs

133 of Nereocystis luetkeana were swabbed with a sterile swab and brushed with an interdental brush

134 (GUM Proxabrush Go-Betweens). We preserved sections of the rhizomes of Phyllospadix

135 scouleri, P. serrulatus and Zostera marina. Sediment surrounding $P$. scouleri and Z. marina was

136 also collected. All samples were collected from Tatoosh Island, WA, USA (48.393679, -

137 124.734617) on 16-17 Jul 2019, except for Z. marina samples which were sampled from West 
138 Falmouth Bay, MA, USA (41.60708333, -70.64527778) on 19 Sept 2019. We included samples

139 from the rhizosphere of Z. marina from the Atlantic Ocean as a known positive control for

140 nitrogen fixation $(22,23)$. Swabs, tissue and sediment were immediately frozen at $20^{\circ} \mathrm{C}$ and

141 shipped to storage at $-80^{\circ}$ C. DNA from these collections was extracted with a Qiagen PowerSoil

142 Kit and multiple samples were pooled for each metagenome sample to increase DNA quantity

143 and possible discovery: P. scouleri blade, rhizome and sediment (3 pooled individuals each), $P$.

144 serrulatus rhizome (3 individuals), L. setchellii blade (3 individuals), N. luetkeana interior bulb

145 (4 individuals), Z. Marina rhizomes and sediment (2 individuals).

147 Shotgun metagenomic sequencing, assembly, and read recruitment

148 The above 8 samples were run over 2 lanes on a HiSeq 2500 (2x150) with TruSeq DNA library

149 preps at Argonne National Laboratory. For each sample, resulting DNA sequences were first

150 quality filtered (35)(Minoche et al. 2011), then assembled with IDBA-UD v1.1.3 (36) (Peng et

151 al. 2012) with a minimum scaffold length of $1 \mathrm{kbp}$. Metagenomic short reads from each sample

152 were then recruited back to their corresponding assembled contigs using Bowtie2 (37). Samtools

153 (38) was used to generate sorted and indexed BAM files. Anvi'o v7.0 (39) was used as the

154 command line environment for all downstream analyses. 'anvi-gen-contigs-database' was used

155 to generate anvi'o contigs databases, during which Prodigal v2.6.3 (40) identified open reading

156 frames, and 'anvi-run-hmms' was used to identify genes matching to archaeal and bacterial

157 single-copy core gene collections using HMMER (41). 
160 To reconstruct genomes from the assembled metagenomes, we used a combination of automatic

161 binning via CONCOCT v1.1.0 (42), followed by a manual curation of each MAG as outlined by

162 Shaiber et al. 2020 (43). Genome taxonomy was determined using GTDB v.1.3.0 (44), and 'anvi-

163 run-scg-taxonomy'. We also inferred gene-level taxonomy using Centrifuge v1.0.4 (45) to aid

164 manual curation.

Phylogenomic analysis of MAGs

167 To perform a phylogenomic analysis of our MAGs, we recovered amino acid sequences for 168 bacterial single-copy core genes (SCGs) from each genome (except the only archaeal genome in 169 our collection) using the program 'anvi-get-sequences-for-hmm-hits' with the parameter '--

170 hmm-source 'Bacteria_71' on the ribosomal gene set 'Ribosomal L1-L6` and the flag '--

171 concatenate', which independently aligned each SCG independently using Muscle v3.8.1 (46)

172 before concatenating them into a final superalignment. We then refined the alignment using 173 trimAl v1.4.rev15 (47) to remove any position in the alignment if more than $50 \%$ of the residues

174 were gap characters. A maximum-likelihood phylogeny was inferred using IQTree (48) with

1751,000 bootstrap replicates, and a LG+R6 model best fit our data using ModelFinder (49).

\section{$177 \quad$ Functional analysis of microbial communities}

178 To address the metabolic capabilities of host-associated microbes, we annotated genes in each

179 anvi'o contigs database with 3 different databases using 'anvi-run-kegg-kofams', 'anvi-run-ncbi-

180 cogs', and 'anvi-run-pfams', which used the databases of Kyoto Encyclopedia of Genes and

181 Genomes (KEGG) (50), NCBI's Clusters of Orthologous Genes (COGs) (51) and EBI's Pfam 182 database (52) respectively. We used these annotated genes to test for 1) nitrogen cycling 
183 metabolisms, especially those within the nitrogen-fixation pathway, 2) hydrolases, including

184 ureases, as well as ammonia-lyases, to cleave the $\mathrm{C}-\mathrm{N}$ bonds in amino acids and make

185 ammonium available to the host, 3) vitamin production, namely vitamins $\mathrm{B}_{1}, \mathrm{~B}_{2}, \mathrm{~B}_{7}$ and $\mathrm{B}_{12}$ and

186 4) a set of dissolved organic matter (DOM) transporter genes identified by Poretsky et al. (34)

187 that indicate the ability of the microbial community to assimilate DOM exudates from kelps and

188 surfgrasses. The list of genes used is indicated in Table S4. We additionally developed and used

189 a graph-based algorithm on KEGG definitions for vitamins $\mathrm{B}_{1}, \mathrm{~B}_{2}, \mathrm{~B}_{7}$ and $\mathrm{B}_{12}$ to detect the

190 presence of these biosynthetic pathways (Supplementary Code 1). To expand our functional

191 analysis of kelp blade genes, we included 32 MAGs from the surface of $N$. luetkeana blades that

192 were collected from the same location at the same time using similar methods as those described

193 above (53).

195 Phylogenetic analysis of nifH genes

196 To search for nifH amino acid sequences in our environmental samples, we identified 9 MAGs

197 which contained nifH genes using the KEGG identifier K02588 with e-value < 1e-20. We

198 aligned the AA sequences for these genes against 89 well-characterized reference nifH AA

199 sequences (Table S6) using Muscle v3.8.1 (46) and refined the alignment using trimAl (gap-

200 threshold: 0.5) and 'anvi-script-reformat-fasta' (max-percentage-gap: 50\%). A maximum-

201 likelihood phylogeny was inferred using IQTree (48) with 1,000 bootstrap replicates, and a

202 LG+R5 model best fit our data using ModelFinder (49). nifH genes from the Zostera samples

203 served as positive controls to detect nitrogen fixation genes in other samples. Figures 2, 3, 4 were

204 generated using iTol v5 (54), R v4.0.3 and FigTree respectively. We additionally took tissue

205 samples from $P$. scouleri rhizome $(\mathrm{n}=16)$, basal meristematic region just distal to the sheath 
$206(\mathrm{n}=12)$ and blade $35 \mathrm{~cm}$ above the rhizome $(\mathrm{n}=12)$ to quantify stable isotopes of $\delta 15 \mathrm{~N}$ and

$207 \delta 13 \mathrm{C}$ to look for signatures of nitrogen fixation (methods described in Appendix 1).

209 Quantifying the Oxygen Environment

210 We quantified the oxygen concentrations in proximity to Phyllospadix spp. rhizomes by

211 comparing dissolved oxygen (DO) concentrations in the surrounding seawater and in the

212 sediment around the rhizome. We used a Pyro Science Robust Oxygen Probe (OXROB10,

213 Firesting ${ }^{\mathrm{TM}}$, Pyroscience), and repeated measurements around 0900h across 4 days (7-9 June

214 2019, 13 June 2021) within P. scouleri $(\mathrm{n}=18)$ and $P$. serrulatus $(\mathrm{n}=11)$ rhizomes. Each

215 reading first measured the surrounding seawater after which we gently pushed the tip of the

216 oxygen probe into the sediment and rhizome mass to a depth of $1-3 \mathrm{~mm}$, the typical thickness

217 (pers. observation). We let the probe equilibrate and took a reading at $150 \mathrm{sec}$. This allowed the

218 rhizome oxygen environment to equilibrate after we disturbed the intact rhizome. We compared

219 surrounding water and within-rhizome oxygen using paired t-tests in R.

221 Data Availability

222 In addition to the code available on GitHub (__ $)$, the final MAG database files generated in

223 anvi'o are available on the FigShare repository: (__ $)$. Metagenomic sequence data are

224 available at the NCBI's Sequence Read Archive under accession no. (submission in progress).

Results

227 Surfgrass rhizomes have lower oxygen concentrations than surrounding seawater 
228 The oxygen environment in the rhizomes differed significantly from that of the surrounding

229 seawater (Fig. 1). Rhizomes maintained a lower dissolved oxygen (DO) concentration than the

230 surrounding seawater for both $P$. scouleri $(\mathrm{n}=18$, pairwise t-test: $p<0.001)$ and $P$. serrulatus

231 (n=11, pairwise t-test: $p<0.001)$. P. serrulatus maintained a slightly lower DO concentration in

232 the rhizome at $2.11 \mathrm{mg} \mathrm{l}^{-1}$, compared to $5.61 \mathrm{mg}^{-1}$ for $P$. scouleri. However, the nature of

233 sampling likely introduced more oxygenated water from the surrounding water column to the

234 rhizome-sediment microenvironment, suggesting that the actual DO concentration within the

235 sediment is lower than the value reported.

Diversity of MAGs assembled across hosts

238 Following filtering, we obtained an average of 41 million reads per sample (range 6.48 to 67.73

239 million), with $79.8 \%$ of raw reads retained on average. When these reads were assembled into

240 contigs of at least 1000 nucleotides, a mean of 42,026 contigs and a mean of 110,054 genes were

241 present across samples (Table S1).

243 Across 8 metagenomes we manually binned 33 high quality MAGs, defined as having a

244 completion score $>90 \%$ and contamination (or redundancy) $<10 \%$ (Table 2). We also identified

24539 lower quality MAGs that had completion scores between 38 and 93\% and redundancy scores

246 between 0 and 21\% (Table S3). All MAGs were bacterial except for a single archaeal MAG on

247 the rhizome of P. scouleri. The bacterial MAGs spanned 7 phyla, including Proteobacteria

248 ( $\mathrm{n}=34)$, Bacteroidota $(\mathrm{n}=19)$, Verrumicrobia $(\mathrm{n}=2)$, Campylobacterota $(\mathrm{n}=3)$, Desulfobacterota

$249(\mathrm{n}=5)$, and a single MAG in each of Desulfomonadota, Acidobacteriota, and Spirochaetota. The

250 Archaea belonged to the phylum Chrenarchaeota. There were 46 MAGs resolved to the species 
251 level, with 8 to the genus level, 9 to family, 2 to order, and 2 to class level. Five MAGs were

252 resolved only as Bacteria (Table S2).

254 The 72 MAGs belong to diverse microbial phyla, which were distributed across the 5 host

255 species and tissue types (Fig. 2). In some cases, bacterial taxa from kelp blade tissues were most

256 closely related to bacteria collected from the rhizome or sediment of a seagrass, suggesting that

257 closely related bacterial taxa can associate with diverse hosts. Known anaerobic sulfur cyclers

258 like Desulfobulbia, Desulfobacteria, Desulfuromonadia and Campylobacteria (Sulfurovum

259 sp000296775 and Sulfurimonas autotrophica) were exclusively found in the low oxygen rhizome

260 and sediment samples of Zostera marina and Phyllospadix spp. Conversely,

261 Alphaproteobacteria, were exclusively found on surfaces exposed to the water column.

262 Gammaproteobacteria was the only class found across the range of tissue types (6 out of 8 host

263 environments). We did not include the only well-resolved archaeal taxon found in our samples,

264 Crenarchaea (P. scouleri rhizome), as our analysis compared single-copy core genes specific to

265 bacterial phyla.

267 Host-associated microbial genomes contain pathways to synthesize vitamins, recycle nitrogen,

268 and use host-generated carbon

269 We found evidence for a number of metabolic pathways that are likely important for exchanges

270 between host phototrophs and their microbial partners (Fig. 3). Microbes on hosts had genes for

271 diverse carbohydrate and carboxylic acid assimilation via cell membrane transport proteins.

272 Host-associated microbes also had genes for a diversity of nitrogen metabolisms, including

273 ureases and hydrolases that could regenerate ammonium. Nitrogen metabolisms were most 
274 diverse in rhizome and sediment samples where we identified both oxidizing (nitrification) and

275 reducing (nitrate reduction, nitrogen fixation, denitrification) metabolisms, as well as

276 metabolisms that both oxidize and reduce (annamox).

278 Every sample had at least one gene from B-vitamins biosynthesis pathways. Using a simple-path

279 based algorithm on KEGG definitions (Supplementary Code 1), we determined that all microbial 280 communities had the metabolic pathways to synthesize vitamins $\mathrm{B}_{1}$ (with the exception of the $P$.

281 scouleri rhizome), $\mathrm{B}_{2}$ and $\mathrm{B}_{7}$ (except inside the bulb of $N$. luetkeana). The Vitamin $\mathrm{B}_{12}$ anaerobic

282 biosynthesis pathway, however, was only present in MAGs found on the blades of L. setchellii

283 (2) and P. scouleri (3) and the rhizomes of P. serrulatus (2) and Z. marina (1). Additionally, all

284 three MAGs on the blade of P. scouleri that had this anaerobic pathway had the genes necessary

285 to synthesize Vitamin $\mathrm{B}_{12}$ aerobically as well.

Novel detection of nifH genes in surfgrass

288 We identified the nitrogenase gene $($ nifH) in 9 MAGs with e-value support $<1.3 \mathrm{e}-120$ (KEGG)

289 and $<1.1$ e-135 (COG). These 9 MAGs were assembled from $P$. serrulatus rhizomes $(\mathrm{n}=2)$ and

290 Z. marina rhizomes $(\mathrm{n}=3)$ and the surrounding sediment $(\mathrm{n}=4)$. Of these 9 MAGs, 5 were

291 resolved to the genus level, while others were resolved to the order and family level, including

292 Campylobacterales, Desulfobacterales and 2 Flavobacteriaceae (Fig. 4, Table S5). nifH genes

293 identified in the rhizomes of $P$. serrulatus and $Z$. marina belonging to the class Desulfobacteria

294 and family Flavobacteriaceae, clustered within Cluster III: anaerobic nitrogen-fixers that are

295 often coupled with sulfate-reduction metabolisms. Samples from Z. marina sediment and

296 rhizome also contained 3 nifH genes in Campylobacterial MAGs that clustered together in a 
297 sister clade to the aerobic nitrogen-fixers of Cluster I. The COG gene identified as nifH

298 (COG1348) also includes the homologous protochlorophyllides, which are involved in

299 photosynthetic pigment synthesis but have high sequence similarity to the nifH gene $(21,55)$.

300 Instead, we used the KEGG gene (K02588) that does not detect these homologs. When we

301 inspected genes on the same contig with nifH, we found a number of genes related to nitrogen

302 fixation (Table S5), including nifD (COG 2710) in 7 of the 9 contigs, nitrogen regulatory protein

303 PII (COG 347), nifB (COG 535), and multiple iron containing proteins including ferrodoxin and

304 Fe-Mo cluster-binding proteins (Table S5).

\section{Discussion}

Phototroph tissues and sediment host distinct microbial taxa and functions

308 The phototroph species we sampled in this study are foundational in coastal ecosystems (56-59),

309 yet a description of the diversity and function of their microbiomes have been lacking. All

310 MAGs were bacterial, except for a single archaeal MAG (Crenarchaeota) in the rhizome of

311 Phyllospadix scouleri, which was identified as Nitrosopumulis, a genus associated with

312 nitrification (Table S3). Together, these 5 phototrophs hosted bacteria from 9 phyla. The only

313 low diversity sample was the interior of the bulb of Nereocystis, where we assembled only a

314 single MAG (UBA7415 sp002470515) suggesting that this environment of high carbon

315 monoxide and nitrogen gas (60) may inhibit microbial activity or pose a highly selective

316 environment. Blades of kelp and surfgrass, in contrast, were a locus of microbial diversity and

317 function, a finding that is similar to many recent studies of macroalgal and seagrass microbiomes

318 reporting high microbial diversity $(2,4,5,61-63)$. The functional attributes of microbial taxa

319 associated with marine macrophytes include pathogen resistance (64), the ability to provision the 
320 host with B vitamins (9), and enhanced host algal fitness (65), perhaps through some of the

321 nitrogen metabolisms we documented here $(14,66)$.

Host-microbe interactions in a dynamic oxygen microenvironment

324 Grouping MAGs by microbial metabolisms (Fig. 3) showed key functional differences among

325 phototroph hosts. Blade tissues that interacted directly with the water column were associated

326 with microbial nitrogen metabolisms that were mostly oxidizing. The abundance of dissolved

327 organic carbon from phototroph hosts $(29-31,59)$ might select for heterotrophic metabolisms.

328 Indeed, we found an abundance of genes for dissolved organic matter assimilation and transport

329 in all metagenomes, suggesting that hosts may stimulate heterotrophy in their associated

330 microbial community similar to findings by Poretsky et al. (34). Improved characterization of the

331 components of dissolved organic matter and the genomes of hosts will allow us to better assess

332 complementarity in resource supply by hosts and resource use by microbes.

334 The host tissue types in this study differed in surface oxygen concentrations. Blade tissue

335 interacts with the water column and is likely more oxygenated than rhizome tissue or sediments,

336 though a previous study suggests there can also be a $60 \%$ reduction in oxygen along the

337 immediate surface of kelp blades (67), and along the mucus layer where some kelp-associated

338 bacteria reside (6). Over two-thirds of the bacterial taxa on blades of $N$. luetkeana belonged to

339 families associated with obligately aerobic metabolisms, demonstrating the role of oxygen in

340 shaping phototroph-associated microbial communities (68). The sediment surrounding the

341 rhizomes of Phyllospadix spp. contained low oxygen microenvironments (Fig. 1) likely

342 maintained by macroinvertebrate respiration (69)(Moulton and Hacker 2011), similar to the 
343 biological processes in the anaerobic sediment surrounding Zostera (13). Low rhizosphere

344 oxygen concentrations likely structured the taxonomic composition of Z. marina to include

345 anaerobic taxa such as Campylobacteria, Desulfatitalea and Desulfobulbus. The presence of

346 anaerobes like Desulfuromonadia, Desulfobaceria, Spirochaeta and Aminicenantia in $P$.

347 serrulatus rhizomes suggests sulfate reduction also occurs, possibly coupled to dissolved organic

348 carbon use as an energy source (e.g. (70) Howarth \& Hobbie 1982). Additionally,

349 Campylobacteria and the genus Thiodiazotropha were associated with Z. marina and may

350 remove detrimental sulfide accumulation through sulfur oxidation $(71,72)$.

352 Nitrogen metabolisms that were both oxidizing and reducing were found in MAGs associated

353 with rhizomes of both Z. marina and Phyllospadix (Fig. 3), suggesting the potential for temporal

354 niches when, for example, ammonium oxidation to nitrate occurs during high- $\mathrm{O}_{2}$ daylight

355 periods, followed by nitrate reduction or nitrogen fixation during $\mathrm{O}_{2}$-depleted nighttime hours.

356 Additionally, all MAGs in this study contained hydrolases that cleave carbon-nitrogen bonds to

357 produce ammonium (14), recycling nitrogen compounds for host uptake. Oxidizing and reducing

358 metabolisms are likely separated only by microns in the hosts studied here.

360 We detected biosynthetic pathways for vitamins $\mathrm{B}_{1}, \mathrm{~B}_{2}, \mathrm{~B}_{7}$ and $\mathrm{B}_{12}$ that are required by the

361 auxotrophic phototroph hosts in this study $(9,10,73)$. We found that only the blades of $P$.

362 scouleri harbored MAGs with both anaerobic and aerobic biosynthetic pathways for Vitamin

$363 \mathrm{~B}_{12}$, suggesting that the variable oxygen environment driven by host-metabolism creates diverse

364 metabolic niches for associated microbes. Strong gradients in oxygen and metabolically diverse

365 microbial metabolisms are present in a diversity of animal hosts such as corals and sponges as a 
result of host metabolism (74-76). Fluctuating oxygen microenvironments might also promote

367 cross-feeding, where microbial taxa produce a metabolite that can be consumed by other taxa.

368 Cross-feeding is potentially important for nitrogen $(77)$ and carbon metabolisms $(78,79)$ in

369 microbial communities.

371 Characteristics of previously undescribed nitrogen fixation in surfgrass

372 Building on recent studies that illustrate the association of nitrogen fixing microbes with a

373 diversity of macroalgae (80) and seagrasses $(22,23,81,82)$, we found a previously undescribed

374 diversity of nitrogenase genes associated with the surfgrass Phyllospadix. We detected nifH

375 genes in P. serrulatus rhizomes that resolved into the Cluster I group of nifH genes, which are

376 characterized by aerobic nitrogen fixers. $P$. serrulatus, in comparison to $P$. scouleri, is found

377 higher up in the intertidal zone and often in sheltered tidepools that tend to undergo dramatic

378 daily fluctuations in oxygen, possibly allowing for a temporal low- $\mathrm{O}_{2}$ niche during the night

379 (83). Conversely, we did not detect nitrogenase genes in the microbiome of $P$. scouleri, which

380 inhabits more wave-exposed and thus better oxygenated environments (Fig. 1). However, stable

381 isotope analyses across $P$. scouleri samples show a lower nitrogen isotopic signature in the

382 rhizome compared to the rest of the plant, a possible indication of nitrogen from an atmospheric

383 source (Fig. S1), though in situ experiments with stable isotope tracers are needed to confirm the

384 presence of nitrogen fixation.

386 Nitrogen fixation by microbial associates provides a key means of increasing the availability of

387 ammonium, possibly supporting primary productivity. $P$. scouleri biomass reaches $12.7 \mathrm{~kg}$ of

388 wet mass per square meter of shore and exudes $0.93 \mathrm{mg} \mathrm{C}$ per hour per gram dry mass as 
dissolved organic carbon that may fuel microbial activity (59). There is evidence that nitrogen

390 fixation can contribute to seagrass productivity $(66,84)$, a possible adaptation to low nitrogen

391 environments. Our finding that nitrogen fixing microbes are associated with a rocky intertidal

392 surfgrass is especially surprising given that Tatoosh Island is in an area of upwelling and high

393 DIN (86) at the more northerly end of the California Current Large Marine Ecosystem. Whether

394 nitrogen fixation forms the basis for reciprocal host-microbe exchange is still unknown.

396 The metagenomic analyses we present here suggest that phototroph-associated microbiomes may

397 be involved in carbon, nitrogen and vitamin metabolisms important to their hosts, likely

398 generating commensal or mutualistic interactions. Future experiments should test these

399 hypothesized interactions between host and microbiome. The importance of seaweeds and

400 seagrasses to coastal productivity, and the demonstrated sensitivity of both host and microbes to

401 increasing temperatures and $\mathrm{pH}(11,62,85)$, pathogens $(61)$, and other anthropogenic stressors,

402 underline the importance of further studying phototroph-microbiome interactions.

\section{Acknowledgements}

405 Our gratitude to the Makah Tribal Nation for access to Tatoosh Island. We thank The University

406 of Chicago's Microbiome Center for pilot award funding, and Washington Department of

407 Natural Resources grants 93099282, 93100399 (CAP) and NSF-DEB grant (\#1556874) awarded

408 to JT Wootton. We appreciate the work of C Sauceda in the isotope analysis, and A Wootton, A

409 Wood and K Foreman in the field sampling. KM was supported by an EE Fellowship from The

410 University of Chicago. S Owens and S Greenwald at Argonne National Lab provided expertise

411 in sequencing. 


\section{References}

413 1. McFall-Ngai M, Hadfield MG, Bosch TCG, Carey HV, Domazet-Lošo T, Douglas AE,

414 Dubilier N, Eberl G, Fukami T, Gilbert SF, Hentschel U, King N, Kjelleberg S, Knoll AH,

415 Kremer N, Mazmanian SK, Metcalf JL, Nealson K, Pierce NE, Rawls JF, Reid A, Ruby EG,

416 Rumpho M, Sanders JG, Tautz D, Wernegreen JJ. 2013. Animals in a bacterial world, a new

417 imperative for the life sciences. Proc Natl Acad Sci USA 110:3229-3236.

418 2. Weigel BL, Pfister CA. 2019. Successional Dynamics and Seascape-Level Patterns of

419 Microbial Communities on the Canopy-Forming Kelps Nereocystis luetkeana and Macrocystis 420 pyrifera. Frontiers in Microbiology 10:346.

421 3. Lemay MA, Martone PT, Keeling PJ, Burt JM, Krumhansl KA, Sanders RD, Wegener

422 Parfrey L. 2018. Sympatric kelp species share a large portion of their surface bacterial

423 communities: Kelp-associated bacterial diversity. Environmental Microbiology 20:658-670.

424 4. Quigley CTC, Capistrant-Fossa KA, Morrison HG, Johnson LE, Morozov A, Hertzberg 425 VS, Brawley SH. 2020. Bacterial Communities Show Algal Host (Fucus spp.)/Zone

426 Differentiation Across the Stress Gradient of the Intertidal Zone. Front Microbiol 11:563118.

427 5. Lemay MA, Davis KM, Martone PT, Parfrey LW. 2021. Kelp-associated Microbiota are 428 Structured by Host Anatomy ${ }^{1}$. J Phycol 57:1119-1130.

429 6. Ramirez-Puebla ST, Weigel BL, Jack L, Schlundt C, Pfister CA, Mark Welch JL. 2020.

430 Spatial organization of the kelp microbiome at micron scales. preprint, Microbiology.

$4317 . \quad$ Jacoby R, Peukert M, Succurro A, Koprivova A, Kopriva S. 2017. The Role of Soil

432 Microorganisms in Plant Mineral Nutrition - Current Knowledge and Future Directions. Front

433 Plant Sci 8:1617.

434 8. Mills MM, Turk-Kubo KA, van Dijken GL, Henke BA, Harding K, Wilson ST, Arrigo 
435 KR, Zehr JP. 2020. Unusual marine cyanobacteria/haptophyte symbiosis relies on N2 fixation 436 even in N-rich environments. The ISME Journal https://doi.org/10.1038/s41396-020-0691-6.

437 9. Croft MT, Lawrence AD, Raux-Deery E, Warren MJ, Smith AG. 2005. Algae acquire

438 vitamin B12 through a symbiotic relationship with bacteria. Nature 438:90-93.

439 10. Wichard T, Charrier B, Mineur F, Bothwell JH, Clerck OD, Coates JC. 2015. The green

440 seaweed Ulva: a model system to study morphogenesis. Front Plant Sci 6.

441 11. Qiu Z, Coleman MA, Provost E, Campbell AH, Kelaher BP, Dalton SJ, Thomas T,

442 Steinberg PD, Marzinelli EM. 2019. Future climate change is predicted to affect the microbiome 443 and condition of habitat-forming kelp. Proceedings of the Royal Society B: Biological Sciences $444 \quad 286: 20181887$.

445 12. Bell W, Mitchell R. 1972. Chemotactic and Growth Responses of Marine Bacteria to 446 Algal Extracellular Products. Biological Bulletin 143:265-277.

447 13. Brodersen KE, Siboni N, Nielsen DA, Pernice M, Ralph PJ, Seymour J, Kühl M. 2018. 448 Seagrass rhizosphere microenvironment alters plant-associated microbial community 449 composition. Environ Microbiol 20:2854-2864.

450 14. Tarquinio F, Bourgoure J, Koenders A, Laverock B, Säwström C, Hyndes GA. 2018.

451 Microorganisms facilitate uptake of dissolved organic nitrogen by seagrass leaves. The ISME

452 Journal https://doi.org/10.1038/s41396-018-0218-6.

453 15. Ladd JN, Jackson RB. 1982. Biochemistry of Ammonification, p. 173-228. In Stevenson, 454 FJ (ed.), Agronomy Monographs. American Society of Agronomy, Crop Science Society of 455 America, Soil Science Society of America, Madison, WI, USA.

456 16. Delmont TO, Quince C, Shaiber A, Esen ÖC, Lee ST, Rappé MS, McLellan SL, Lücker 457 S, Eren AM. 2018. Nitrogen-fixing populations of Planctomycetes and Proteobacteria are 
abundant in surface ocean metagenomes. Nature Microbiology 3:804-813.

459 17. Sohm JA, Webb EA, Capone DG. 2011. Emerging patterns of marine nitrogen fixation.

$460 \quad$ Nat Rev Microbiol 9:499-508.

461 18. Bombar D, Paerl RW, Riemann L. 2016. Marine Non-Cyanobacterial Diazotrophs:

462 Moving beyond Molecular Detection. Trends in Microbiology 24:916-927.

463 19. Harding K, Turk-Kubo KA, Sipler RE, Mills MM, Bronk DA, Zehr JP. 2018. Symbiotic

464 unicellular cyanobacteria fix nitrogen in the Arctic Ocean. Proc Natl Acad Sci USA 115:13371-

46513375.

466 20. Cabello AM, Turk-Kubo KA, Hayashi K, Jacobs L, Kudela RM, Zehr JP. 2020.

467 Unexpected presence of the nitrogen-fixing symbiotic cyanobacterium UCYN-A in Monterey

468 Bay, California. J Phycol 56:1521-1533.

469 21. Raymond J, Siefert JL, Staples CR, Blankenship RE. 2004. The Natural History of

470 Nitrogen Fixation. Molecular Biology and Evolution 21:541-554.

471 22. Patriquin D, Knowles R. 1972. Nitrogen fixation in the rhizosphere of marine

472 angiosperms. Marine Biology 16:49-58.

473 23. Capone DG. 1982. Nitrogen Fixation (Acetylene Reduction) by Rhizosphere Sediments

474 of the Eelgrass Zostera marina. Marine Ecology Progress Series 10:67-75.

475 24. Cole L, McGlathery K. 2012. Nitrogen fixation in restored eelgrass meadows. Marine

476 Ecology Progress Series 448:235-246.

477 25. Agawin N, Ferriol P, Sintes E. 2019. Simultaneous measurements of nitrogen fixation in 478 different plant tissues of the seagrass Posidonia oceanica. Mar Ecol Prog Ser 611:111-127.

479 26. Aoki L, McGlathery K. 2019. High rates of $\mathrm{N}$ fixation in seagrass sediments measured 480 via a direct 30N2 push-pull method. Mar Ecol Prog Ser 616:1-11. 
481 27. Massey V. 2000. The chemical and biological versatility of riboflavin. 28:283-296.

482 28. Grossman A. 2016. Nutrient Acquisition: The Generation of Bioactive Vitamin B 12 by

483 Microalgae. Current Biology 26:R319-R321.

484 29. Reed DC, Carlson CA, Halewood ER, Nelson JC, Harrer SL, Rassweiler A, Miller RJ.

485 2015. Patterns and controls of reef-scale production of dissolved organic carbon by giant kelp $M$

486 acrocystis pyrifera: DOC production by giant kelp. Limnology and Oceanography 60:1996-

4872008.

488 30. Weigel BL, Pfister CA. 2021. The dynamics and stoichiometry of dissolved organic 489 carbon release by kelp. Ecology 102.

490 31. Wetzel RG, Penhale PA. 1979. Transport of carbon and excretion of dissolved organic

491 carbon by leaves and roots/rhizomes in seagrasses and their epiphytes. Aquatic Botany 6:149-

492158

493 32. Barrón C, Apostolaki ET, Duarte CM. 2014. Dissolved organic carbon fluxes by seagrass 494 meadows and macroalgal beds. Frontiers in Marine Science 1.

495 33. Pfister CA, Altabet MA. 2019. Enhanced microbial nitrogen transformations in

496 association with macrobiota from the rocky intertidal. Biogeosciences 16:193-206.

497 34. Poretsky RS, Sun S, Mou X, Moran MA. 2010. Transporter genes expressed by coastal

498 bacterioplankton in response to dissolved organic carbon. Environmental Microbiology 12:616-

499627.

500 35. Minoche AE, Dohm JC, Himmelbauer H. 2011. Evaluation of genomic high-throughput 501 sequencing data generated on Illumina HiSeq and Genome Analyzer systems. Genome Biol

$502 \quad 12: R 112$.

503 36. Peng Y, Leung HCM, Yiu SM, Chin FYL. 2012. IDBA-UD: a de novo assembler for 
504 single-cell and metagenomic sequencing data with highly uneven depth. Bioinformatics

$505 \quad 28: 1420-1428$.

506 37. Langmead B, Salzberg SL. 2012. Fast gapped-read alignment with Bowtie 2. Nat

507 Methods 9:357-359.

508 38. Li H, Handsaker B, Wysoker A, Fennell T, Ruan J, Homer N, Marth G, Abecasis G,

509 Durbin R, 1000 Genome Project Data Processing Subgroup. 2009. The sequence alignment/map

510 format and SAMtools. Bioinformatics 25:2078-2079.

511 39. Eren AM, Kiefl E, Shaiber A, Veseli I, Miller SE, Schechter MS, Fink I, Pan JN, Yousef

512 M, Fogarty EC, Trigodet F, Watson AR, Esen ÖC, Moore RM, Clayssen Q, Lee MD, Kivenson

513 V, Graham ED, Merrill BD, Karkman A, Blankenberg D, Eppley JM, Sjödin A, Scott JJ,

514 Vázquez-Campos X, McKay LJ, McDaniel EA, Stevens SLR, Anderson RE, Fuessel J,

515 Fernandez-Guerra A, Maignien L, Delmont TO, Willis AD. 2021. Community-led, integrated,

516 reproducible multi-omics with anvi'o. Nat Microbiol 6:3-6.

517 40. Hyatt D, Chen G-L, LoCascio PF, Land ML, Larimer FW, Hauser LJ. 2010. Prodigal:

518 prokaryotic gene recognition and translation initiation site identification. BMC Bioinformatics

$519 \quad 11: 119$.

520 41. Eddy SR. 2011. Accelerated Profile HMM Searches. PLoS Comput Biol 7:e1002195.

521 42. Alneberg J, Bjarnason BS, de Bruijn I, Schirmer M, Quick J, Ijaz UZ, Lahti L, Loman

522 NJ, Andersson AF, Quince C. 2014. Binning metagenomic contigs by coverage and composition.

523 Nat Methods 11:1144-1146.

524 43. Shaiber A, Willis AD, Delmont TO, Roux S, Chen L-X, Schmid AC, Yousef M, Watson

525 AR, Lolans K, Esen ÖC, Lee STM, Downey N, Morrison HG, Dewhirst FE, Mark Welch JL,

526 Eren AM. 2020. Functional and genetic markers of niche partitioning among enigmatic members 
527 of the human oral microbiome. Genome Biol 21:292.

528 44. Parks DH, Chuvochina M, Rinke C, Mussig AJ, Chaumeil P-A, Hugenholtz P. 2021.

529 GTDB: an ongoing census of bacterial and archaeal diversity through a phylogenetically

530 consistent, rank normalized and complete genome-based taxonomy. Nucleic Acids Research

531 gkab776.

532 45. Kim D, Song L, Breitwieser FP, Salzberg SL. 2016. Centrifuge: rapid and sensitive

533 classification of metagenomic sequences. Genome Res 26:1721-1729.

534 46. Edgar RC. 2004. MUSCLE: multiple sequence alignment with high accuracy and high

535 throughput. Nucleic Acids Research 32:1792-1797.

536 47. Capella-Gutierrez S, Silla-Martinez JM, Gabaldon T. 2009. trimAl: a tool for automated

537 alignment trimming in large-scale phylogenetic analyses. Bioinformatics 25:1972-1973.

538 48. Nguyen L-T, Schmidt HA, von Haeseler A, Minh BQ. 2015. IQ-TREE: A Fast and

539 Effective Stochastic Algorithm for Estimating Maximum-Likelihood Phylogenies. Molecular

540 Biology and Evolution 32:268-274.

541 49. Kalyaanamoorthy S, Minh BQ, Wong TKF, von Haeseler A, Jermiin LS. 2017.

542 ModelFinder: fast model selection for accurate phylogenetic estimates. Nat Methods 14:587-

543589

544 50. Kanehisa M. 2000. KEGG: Kyoto Encyclopedia of Genes and Genomes. Nucleic Acids

545 Research 28:27-30.

546 51. Galperin MY, Makarova KS, Wolf YI, Koonin EV. 2015. Expanded microbial genome

547 coverage and improved protein family annotation in the COG database. Nucleic Acids Research

$548 \quad$ 43:D261-D269.

549 52. Mistry J, Chuguransky S, Williams L, Qureshi M, Salazar GA, Sonnhammer ELL, 
550 Tosatto SCE, Paladin L, Raj S, Richardson LJ, Finn RD, Bateman A. 2021. Pfam: The protein

551 families database in 2021. Nucleic Acids Research 49:D412-D419.

552 53. Weigel BL, Miranda KK, Fogarty EC, Watson AR, Pfister CA. in review. Functional

553 insights into the kelp microbiome from metagenome assembled genomes.

554 54. Letunic I, Bork P. 2021. Interactive Tree Of Life (iTOL) v5: an online tool for

555 phylogenetic tree display and annotation. Nucleic Acids Research 49:W293-W296.

556 55. Kapili BJ, Dekas AE. 2021. PPIT: an R package for inferring microbial taxonomy from

557 nifH sequences. Bioinformatics 37:2289-2298.

558 56. Shelton AO. 2010. Temperature and community consequences of the loss of foundation

559 species: Surfgrass (Phyllospadix spp., Hooker) in tidepools. Journal of Experimental Marine

560 Biology and Ecology 391:35-42.

561 57. Lefcheck JS, Wilcox DJ, Murphy RR, Marion SR, Orth RJ. 2017. Multiple stressors

562 threaten the imperiled coastal foundation species eelgrass ( Zostera marina) in Chesapeake Bay,

563 USA. Glob Change Biol 23:3474-3483.

564 58. Pfister CA, Altabet MA, Weigel BL. 2019. Kelp beds and their local effects on seawater

565 chemistry, productivity, and microbial communities. Ecology https://doi.org/10.1002/ecy.2798.

566 59. Miranda KK, Weigel BL, McCoy SJ, Pfister CA. 2021. Differential impacts of alternate

567 primary producers on carbon cycling. Ecology https://doi.org/10.1002/ecy.3455.

568 60. Liggan LM, Martone PT. 2018. Under pressure: biomechanical limitations of developing

569 pneumatocysts in the bull kelp ( Nereocystis luetkeana, Phaeophyceae). Journal of Phycology

$570 \quad 54: 608-615$.

571 61. Egan S, Harder T, Burke C, Steinberg P, Kjelleberg S, Thomas T. 2013. The seaweed

572 holobiont: understanding seaweed-bacteria interactions. FEMS Microbiology Reviews 37:462- 
573476.

574 62. Minich JJ, Morris MM, Brown M, Doane M, Edwards MS, Michael TP, Dinsdale EA.

575 2018. Elevated temperature drives kelp microbiome dysbiosis, while elevated carbon dioxide

576 induces water microbiome disruption. PLOS ONE 13:e0192772.

577 63. Capistrant-Fossa KA, Morrison HG, Engelen AH, Quigley CTC, Morozov A, Serrão EA,

578 Brodie J, Gachon CMM, Badis Y, Johnson LE, Hoarau G, Abreu MH, Tester PA, Stearns LA,

579 Brawley SH. 2021. The microbiome of the habitat-forming brown alga Fucus vesiculosus

580 (Phaeophyceae) has similar cross-Atlantic structure that reflects past and present drivers ${ }^{1} . \mathrm{J}$

$581 \quad$ Phycol jpy.13194.

582 64. Li J, Weinberger F, Saha M, Majzoub ME, Egan S. 2021. Cross-Host Protection of

583 Marine Bacteria Against Macroalgal Disease. Microb Ecol https://doi.org/10.1007/s00248-021-

$584 \quad 01909-2$.

585 65. Burgunter-Delamare B, KleinJan H, Frioux C, Fremy E, Wagner M, Corre E, Le Salver

586 A, Leroux C, Leblanc C, Boyen C, Siegel A, Dittami SM. 2020. Metabolic Complementarity

587 Between a Brown Alga and Associated Cultivable Bacteria Provide Indications of Beneficial

588 Interactions. Front Mar Sci 7:85.

589 66. Mohr W, Lehnen N, Ahmerkamp S, Marchant HK, Graf JS, Tschitschko B, Yilmaz P,

590 Littmann S, Gruber-Vodicka H, Leisch N, Weber M, Lott C, Schubert CJ, Milucka J, Kuypers

591 MMM. 2021. Terrestrial-type nitrogen-fixing symbiosis between seagrass and a marine

592 bacterium. Nature https://doi.org/10.1038/s41586-021-04063-4.

593 67. Noisette F, Hurd C. 2018. Abiotic and biotic interactions in the diffusive boundary layer

594 of kelp blades create a potential refuge from ocean acidification. Functional Ecology 32:1329-

5951342. 
596 68. Weigel BL, Pfister CA. 2020. Oxygen metabolism shapes microbial settlement on

597 photosynthetic kelp blades compared to artificial kelp substrates. Environmental Microbiology

598 Reports 1758-2229.12923.

599 69. Moulton O, Hacker S. 2011. Congeneric variation in surfgrasses and ocean conditions

600 influence macroinvertebrate community structure. Mar Ecol Prog Ser 433:53-63.

601 70. Howarth RW, Hobbie JE. 1982. THE REGULATION OF DECOMPOSITION AND

602 HETEROTROPHIC MICROBIAL ACTIVITY IN SALT MARSH SOILS: A REVIEW, p. 183-

603 207. In Estuarine Comparisons. Elsevier.

604 71. Martin BC, Middleton JA, Fraser MW, Marshall IPG, Scholz VV, Hausl B, Schmidt H.

605 2020. Cutting out the middle clam: lucinid endosymbiotic bacteria are also associated with

606 seagrass roots worldwide. ISME J 14:2901-2905.

607 72. Keller AH, Schleinitz KM, Starke R, Bertilsson S, Vogt C, Kleinsteuber S. 2015.

608 Metagenome-Based Metabolic Reconstruction Reveals the Ecophysiological Function of

609 Epsilonproteobacteria in a Hydrocarbon-Contaminated Sulfidic Aquifer. Front Microbiol 6.

610 73. Helliwell KE. 2017. The roles of B vitamins in phytoplankton nutrition: new perspectives

611 and prospects. New Phytol 216:62-68.

612 74. Babbin AR, Tamasi T, Dumit D, Weber L, Rodríguez MVI, Schwartz SL, Armenteros M,

613 Wankel SD, Apprill A. 2021. Discovery and quantification of anaerobic nitrogen metabolisms

614 among oxygenated tropical Cuban stony corals. ISME J 15:1222-1235.

615 75. Fiore CL, Jarett JK, Olson ND, Lesser MP. 2010. Nitrogen fixation and nitrogen

616 transformations in marine symbioses. Trends in Microbiology 18:455-463.

617 76. Morris RL, Schmidt TM. 2013. Shallow breathing: bacterial life at low O2. Nature

618 Reviews Microbiology 11:205-212. 
619 77. Lilja EE, Johnson DR. 2019. Substrate cross-feeding affects the speed and trajectory of

620 molecular evolution within a synthetic microbial assemblage. BMC Evol Biol 19:129.

621 78. de Jesús Astacio LM, Prabhakara KH, Li Z, Mickalide H, Kuehn S. 2020. Closed

622 microbial communities self-organize to persistently cycle carbon. preprint, Ecology.

623 79. Goldford JE, Lu N, Bajić D, Estrela S, Tikhonov M, Sanchez-Gorostiaga A, Segrè D,

624 Mehta P, Sanchez A. 2018. Emergent simplicity in microbial community assembly. Science $625 \quad 361: 469-474$.

626 80. Hamersley MR, Sohm JA, Burns JA, Capone DG. 2015. Nitrogen fixation associated 627 with the decomposition of the giant kelp Macrocystis pyrifera. Aquatic Botany 125:57-63.

628 81. McGlathery K, Risgaard-Petersen N, Christensen P. 1998. Temporal and spatial variation

629 in nitrogen fixation activity in the eelgrass Zostera marina rhizosphere. Mar Ecol Prog Ser

$630 \quad 168: 245-258$.

631 82. Garcias-Bonet N, Arrieta JM, Duarte CM, Marbà N. 2016. Nitrogen-fixing bacteria in

632 Mediterranean seagrass (Posidonia oceanica) roots. Aquatic Botany 131:57-60.

633 83. Steunou A-S, Jensen SI, Brecht E, Becraft ED, Bateson MM, Kilian O, Bhaya D, Ward

634 DM, Peters JW, Grossman AR, Kühl M. 2008. Regulation of nif gene expression and the

635 energetics of N2 fixation over the diel cycle in a hot spring microbial mat. ISME J 2:364-378.

636 84. Cardini U, van Hoytema N, Bednarz VN, Al-Rshaidat MMD, Wild C. 2018. $\mathrm{N}_{2}$ fixation

637 and primary productivity in a red sea Halophila stipulacea meadow exposed to seasonality: $N_{2}$

638 fixation in Halophila stipulacea. Limnol Oceanogr 63:786-798.

639 85. Agawin NSR, Gil Atorrasagasti MG, Frank Comas A, Fernández-Juárez V, López-

640 Alforja X, Hendriks IE. 2021. Response of the seagrass POSIDONIA OCEANICA and its associated

$641 \mathrm{~N}_{2}$ fixers to high business-as-usual climate change scenario in winter. Limnol Oceanogr 
$642 \operatorname{lno.11758.}$

643

644 Table 1. Summary of the features of 8 metagenomes. More information is in Table S1 and the

645 taxonomy based on single copy genes is in Table S2.

\begin{tabular}{cc|c|c|c|c}
\hline & Phyllospadix & Phyllospadix & Laminaria & Nereocystis & Zostera \\
& scouleri & serrulatus & setchellii & luetkeana & marina \\
Sediment & Rhizome Blade & Rhizome & Blade & Inner bulb & Sediment Rhizome \\
\hline
\end{tabular}

\# quality reads (in millions)
43.68
67.73
38.41
37.99
48.58
6.48
19.37
65.76

Bacteria
$63.7 \%$
$58.3 \%$
$63.6 \%$
$63.0 \%$
$63.9 \%$
$62.2 \%$
$33.6 \%$
$60.6 \%$

Archaea

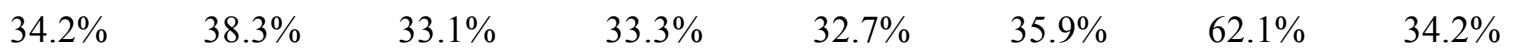

646 
648 Table 2. Metagenome assembled genomes across all samples and their representation across

649 phyla. More detailed information on the MAGs can be found in Table S3.

\begin{tabular}{|c|c|c|c|c|c|c|c|}
\hline \multicolumn{3}{|c|}{$\begin{array}{c}\text { Phyllospadix } \\
\text { scouleri }\end{array}$} & \multirow{2}{*}{$\begin{array}{l}\text { Phyllospadix } \\
\text { serrulatus } \\
\text { Rhizome }\end{array}$} & \multirow{2}{*}{$\begin{array}{l}\text { Laminaria } \\
\text { setchellii } \\
\text { Blade }\end{array}$} & \multirow{2}{*}{$\begin{array}{l}\text { Nereocystis } \\
\text { luetkeana } \\
\text { Inner bulb }\end{array}$} & \multicolumn{2}{|c|}{$\begin{array}{l}\text { Zostera } \\
\text { marina }\end{array}$} \\
\hline Sediment & Rhizome & Blade & & & & Sediment & Rhizome \\
\hline \multicolumn{8}{|c|}{ High Quality MAGs } \\
\hline 3 & 1 & 7 & 6 & 9 & 1 & 2 & 5 \\
\hline \multicolumn{8}{|l|}{ Other MAGs } \\
\hline 2 & 2 & 8 & 7 & 7 & 0 & 5 & 7 \\
\hline \multicolumn{8}{|l|}{ Proteobacteria } \\
\hline 2 & - & 9 & 2 & 10 & 1 & 5 & 5 \\
\hline \multicolumn{8}{|l|}{ Bacteroidota } \\
\hline 3 & 2 & 5 & 4 & 4 & - & - & 1 \\
\hline \multicolumn{8}{|c|}{ Verrucomicrobia } \\
\hline- & - & - & - & 2 & - & - & - \\
\hline \multicolumn{8}{|c|}{ Campylobacterota } \\
\hline- & - & - & - & - & - & 2 & 1 \\
\hline \multicolumn{8}{|c|}{ Desulfobacterota } \\
\hline- & - & - & 2 & - & - & - & 3 \\
\hline \multicolumn{8}{|c|}{ Desulfuromonadota } \\
\hline- & - & - & 1 & - & - & - & - \\
\hline \multicolumn{8}{|c|}{ Acidobacteriota } \\
\hline- & - & - & 1 & - & - & - & - \\
\hline \multicolumn{8}{|l|}{ Spirochaetota } \\
\hline- & - & - & 1 & - & - & - & - \\
\hline \multicolumn{8}{|l|}{ No ID } \\
\hline- & - & 1 & 2 & - & - & - & 2 \\
\hline \multicolumn{8}{|l|}{ Crenarchaeota } \\
\hline- & 1 & - & - & - & - & - & - \\
\hline
\end{tabular}


653 Figure 1. Boxplot comparing the dissolved oxygen concentrations of water column (blue) and

654 the sediment-rhizome environment (red) of $P$. scouleri (pairwise t-test: $\mathrm{p}<0.001$ ) and $P$.

655 serrulatus (pairwise t-test: $\mathrm{p}<0.001$ ). Sampling dates are represented by different colors.

656

657 Figure 2. A phylogenomic tree of 6 concatenated bacterial single-copy core ribosomal genes

658 from 71 bacterial MAGS across 8 samples, showing the results from 33 high quality MAGs and

65938 lower quality ones. One MAG, PSC_RHZ_Bin_00003, from the rhizome of P. scouleri, was 660 identified as an archaeal genome and was thus omitted from this tree. Gaps in class, family and 661 genus indicate the level to which taxonomic classification was resolved in each MAG. All blade 662 tissues have 'water column exposure', while rhizome and sediment samples do not.

663

664 Figure 3. Microbial Metabolisms in the MAGs reported in Fig. 2 and Table S3 across all hosts and grouped as those that might benefit the host ("hosts benefit") and microbial metabolisms that

666 might utilize host provisioned metabolites ("microbes benefit"). Each tick along the x-axis

667 corresponds to a MAG. N. luetkeana blade MAGs are from Weigel et al. (in review). The

668 metabolisms for DOC Uptake that benefit microbes are shown as a heatmap of the count of the

669 number of genes that can metabolize Compatible Solutes, Carboxylic Acids, Carbohydrate

670 Pentoses and General Carbohydrates. Microbial metabolisms that benefit the host are

671 Ammonification Hydrolases, where the heatmap provides a count of the hydrolases acting on

672 C-N bonds other than peptide bonds, Nitrogen Metabolisms and Vitamin Synthesis, both

673 shown as the presence or absence of a gene in a pathway. The genes used in this are in Table S4. 
675 Figure 4. A phylogenomic tree of nifH genes found on the rhizomes of P. serrulatus (PSE,

$676 \mathrm{n}=3$ ) and the rhizomes and surrounding sediment of Z. marina (ZMA, $\mathrm{n}=2$ and 5,

677 respectively). Some nifH genes group into Cluster I, including a sulfur oxidizing taxon on the

678 rhizome of Z. marina, and other taxa in Campylobacterota, including Sulfurovum. Cluster III

679 contains taxa associated with rhizomes including rhizomes including Desulfobulbus

680 mediterraneus on $P$. serrulatus and a Desulfobacterales associated with $Z$. marina rhizomes. 


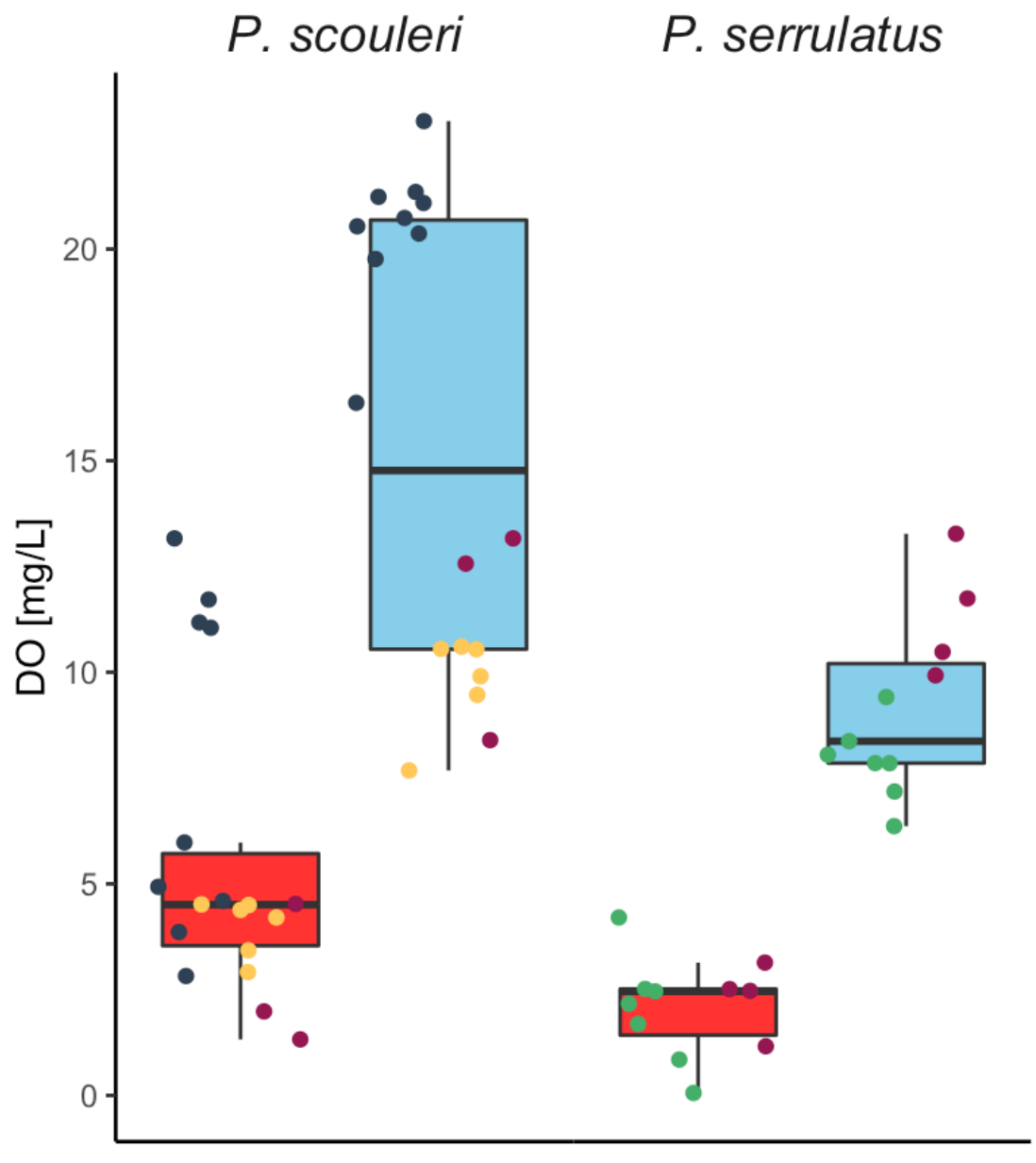

Environment

후 Rhizome

审 Water Column

Figure 1 
bioRxiv preprint doi: https://doi. org/10.1101/2022 01.05.475171; this version posted January 7,2022 The copyright holder for this preprint (which was not certified by peer review) is the author/funder, who has granted bioRxiv a license to display the preprint in perpetuity. It is made available under aCC-BY-ND 4.0 International license.

Tree scale: 1

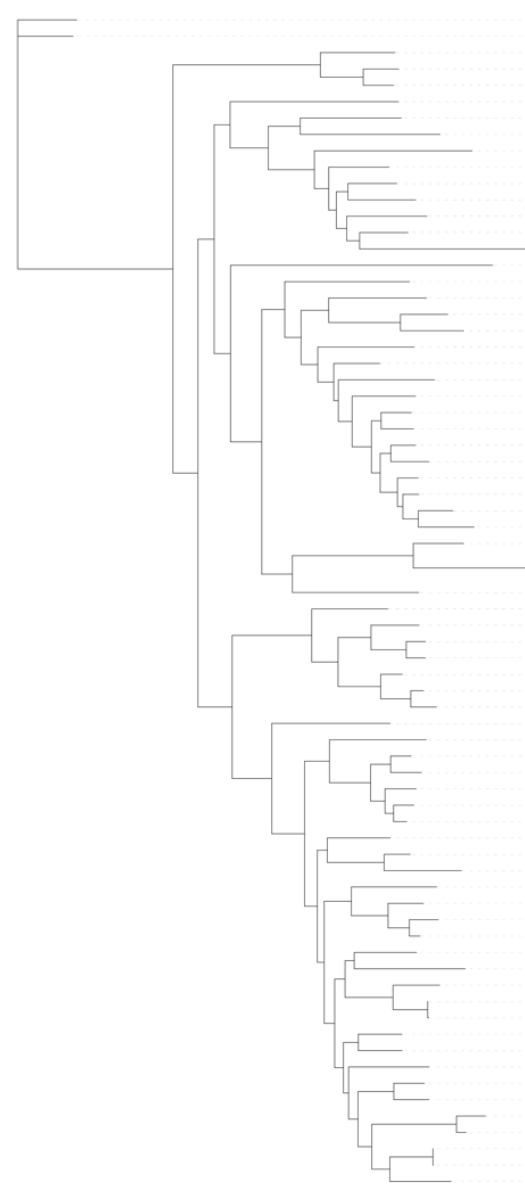

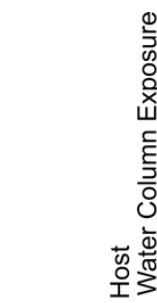

LSE BLD Bin 00008 ZMA SED Bin 00000 ZMA SER B Bn 00000 ZMMSED Bin 00002 PSERHZBin 00000 PSE RHZ Bin 0 o ZMARHZ Bin 0000 ZMA RHZ Bin 0000 ZMARHZ Bin 0000 PIS R PSE RHZBin O000 PSE RHZ Bin 0000

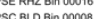
PSC BLD Bin 000010

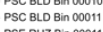

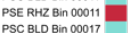
PSC BLD Bin 00017
PSE RRZ Bin 0005
LSE BLD Bin 00002 PSE RHz Bin 0000 PSC BLD Bin 0000 LSE BLD Bin $0000 \mathrm{C}$

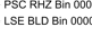
ZMARHZ Bin 00005 SC SED Bin 000000 PSC SEO Bin 00005 PSE RHZ Bin 00000 Psc BLo Bino000

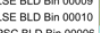

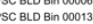
SSE ELD Bin 00012 SSE RHZ Bin 00000 PSC BLD Bin 000005 NLU Ble Bin 000001 PSE RHZ Bin 00015

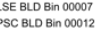
PSC BLD Bin 0001
LSE ELD Bin 0001 LSE BLD Bin 00014

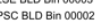
and ZMA RHZ Bin 0000 ZMA RHZ Bin 000 MARHZ Bin 00000 ZMA SED Bin 0000 PAS SED Bn 00005

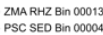
SSE BLD Bin 00018 PSC BLL Bin 00000
PSC BLL Bin 00004

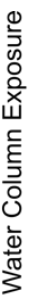

\section{0
$\frac{\pi}{0}$
$\frac{\pi}{U}$}

Verrucomicrobiae
Verrucomicrobiae

Campylobacteria

Campylobacteria
Campylobacteria

Desulfobulbia

Desulfobacteria

Desulfobacteria

Desulfobacteria
Desulfuromonadia

Aminicenantit:
Spirochaetia

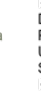

Desultosicist-190-2

SFB93
UBlobacteraceae
UBA2199

Saprospiraceae UBA1994

$\begin{array}{ll}\text { Flavobacteriaceae } & \text { Maribacter } \\ G C A-2748055 & \text { GCA-2748055 }\end{array}$

Flavobacteriaceae
Flavobactericaeae
Flavobachuntrix
UBA7949

Flavobacteriaceae
Flavobacteriaceae

$\begin{array}{ll}\text { Flavobacteriaceae } & \text { Flavobacteriaceae } \\ \text { SZUA-7 }\end{array}$

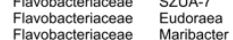

Flavobacteriaceae

Flavobactinaceae Flavobacterium
Flavobacteriaceae

havobatenaceae

Rhodobacteraceae
Maricaulaceae Hellea

$\begin{array}{cc}\text { Maricaulaceae } & \begin{array}{c}\text { Hellea } \\ \text { Maricaulaceae }\end{array} \\ \text { Hellea }\end{array}$

Rhodobacteraceae Amylibacter

Rhodobacteraceaeae

ria Alteromonadaceae Thalassotalea

UBA7415 Teceae Teredinibace

ia UBA7415

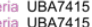

(a)

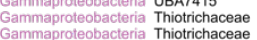

UBA7415
UBA7415
UBA7415

UBA7415

Leucothrix

Granulosicicocaceae GCA-1730015
Granulosicocacaeae Granulosicoccus

Granulosicoccacaceae Greanulosicoccus
Grosioccus

$\begin{array}{lll}\text { Granulosicoccaceae } & \text { Granulosicoccus } \\ \text { GCA-001735895 } & \text { GCA-001735895 }\end{array}$

Sedimenticolaceae 41 TI-STBD-0.-01

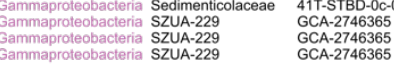

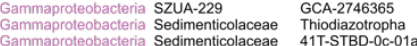

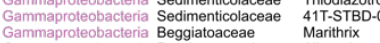

ammaproteobacteria Psychromonadaceae Aliagarivorans

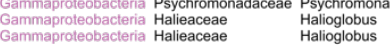

semmaproteobacteria Cellvibrionaceae
Gammaproteobacteria Cellvibrionaceae

Gammaproteobacteria Cellvibrionaceae
Alphaproteobacteria
Maricaulaceae
Host

\author{
L. setchellii Blade \\ P. scouleri Blade \\ P. scouleri Rhizome \\ P. scouleri Sediment \\ P. serrulatus Rhizome \\ Z. marina Rhizome \\ Z. marina Sediiment \\ N. luetkeana Inner bulb
}

\section{Water Column Exposure}

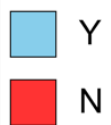

Figure 2 
bioRxiv preprint doi: https://doi.org/10.1101/2022.01.05.475171; this version posted January 7, 2022. The copyright holder for this preprint (which was not certified by peer review) is the author/funder, who has granted bioRxiv a license to display the preprint in perpetuity. It is made available under aCC-BY-ND 4.0 International license.

\section{Gene Count}

$0 \quad 50 \quad 100$

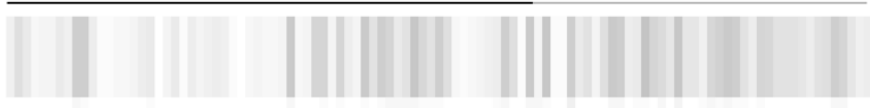

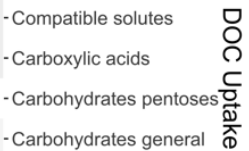

- Carbohydrates general

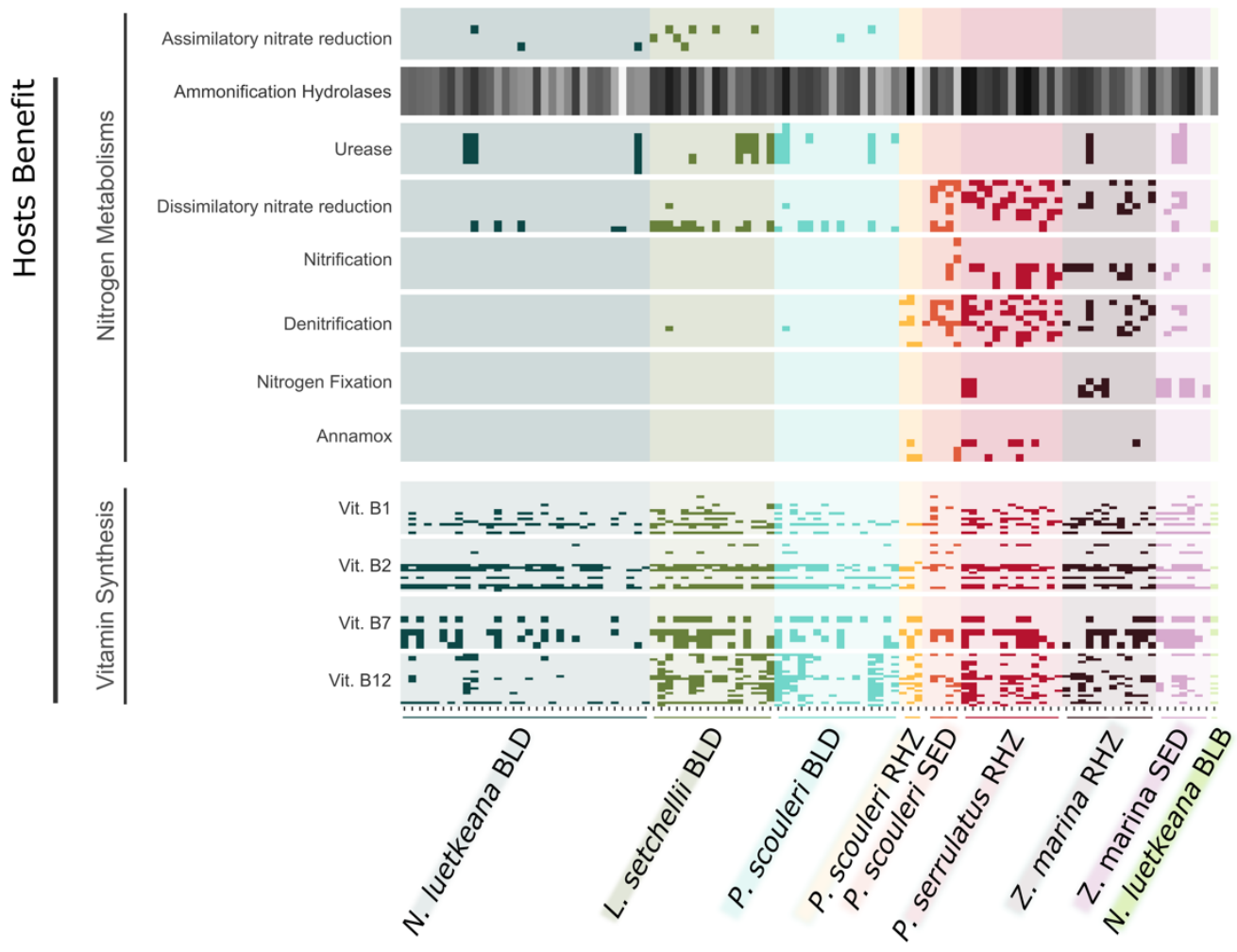


bioRxiv preprint doi: https://doi.org/10.1101/2022.01.05.475171; this version posted January 7, 2022. The copyright holder for this preprint (which was not certified by peer review) is the author/funder, who has granted bioRxiv a license to display the preprint in perpetuity. It is made available under aCC-BY-ND 4.0 International license.

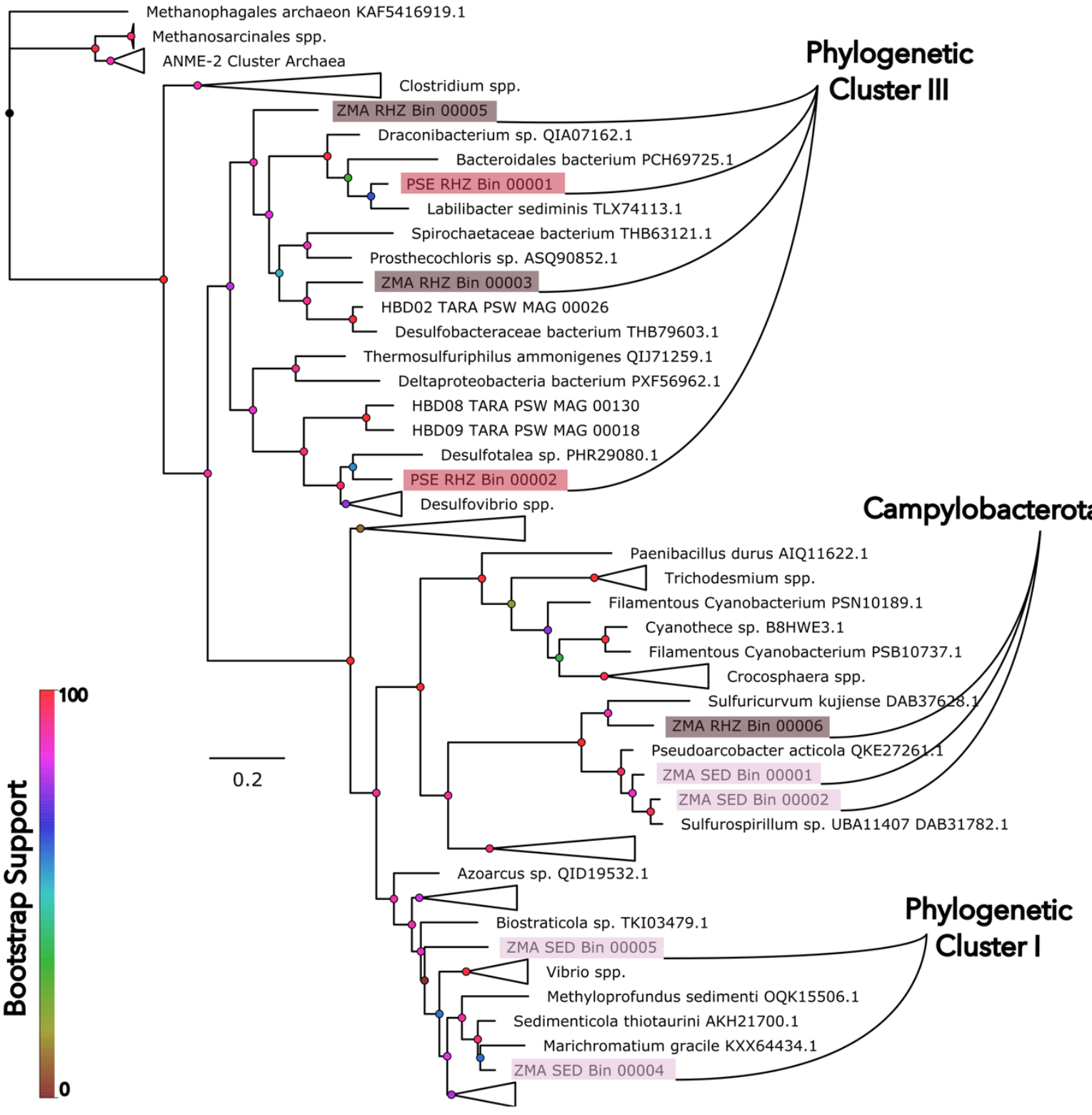




\section{Supplementary Files}

692 Table S1. A summary of eight metagenomes from five macrophyte taxa.

693 Table S2. A summary of taxonomy of MAGs

694 Table S3. The features of 72 metagenome assembled genomes (MAGs).

695 Table S4. Genes used to generate Fig. 3

696 Table S5. The features of nifH genes found in MAGs.

697 Table S6. nifH reference amino acid sequences

698

699 Appendix 1. Additional methods to quantify carbon and nitrogen stable isotopes in P. scouleri

700 Figure S1. Stable isotope analysis of delC13 and delN15 at blade tip, meristem, rhizome of P.

701 scouleri. From blade tip to rhizome, water flow and thus elemental mixing reduces due to

702 attenuation and boundary layer effects of surfgrass canopy. Assuming elemental uptake occurs

703 from the same pools of $\mathrm{C}$ and $\mathrm{N}$, the lower the extent of mixing, the heavier the isotopic

704 signature should be at that point of the plant. This is observed with delC13 which gets heavier

705 from the tip to the blade. This is observed with delN15 till the meristem after which it lightens.

706 This is probably occurring as nitrogen is taken up from a different pool of nitrogen from that

707 around the blade/meristem. This different pool is probably made available through n-fixation 